\title{
A MAGYARORSZÁGI PECSENYECSIRKE-ÁGAZAT MÚLTJA ÉS JELENE, VERSENYKÉPESSÉGÉNEK ELEMZÉSE
}

\author{
Dr. PhD. Vincze-Lendvai Edina \\ föiskolai docens, Szegedi Tudományegyetem Mérnöki Kar
}

\section{Summary}

In Hungary in the last 5 years the meat-production and consumption is uncertain. The habits of the consumers have changed, the meat-prices have grown and new animal-diseases have appeared. The changes reached the poultry-sector too.

In my work I show the development of the poultry branch, examined the broiler sector - its most important factors, and made a SWOT-analysis about the competitiveness of this department.

\section{BEVEZETÉS}

Magyarországon - s némi túlzással azt is mondhatjuk, hogy a világban -, az elmúlt öt év hústermelésére és -fogyasztására a bizonytalanság a legjellemzőbb kifejezés. Ez több okra vezethető vissza. Megváltoztak a fogyasztói szokások - az egészséges táplálkozásra való törekvés került elötérbe, emellett szinte minden évben „napirenden volt" egy új állatbetegség, világméretü járvány (BSE, madárinfluenza), s nem utolsósorban a gazdasági helyzet is változott, a fogyasztói árak egyre emelkednek.

A változások a broilerágazatot sem kímélték. Az elmúlt évben a takarmányár-növekedés, 2006-ban a madárinfluenza veszélye fenyegette. Nemrégiben pedig a „Négy Mancs Alapítvány" miatt kerültek a középpontba.

Munkámban a pecsenyecsirke-ágazatot mutatom be a kialakulástól napjainkig, majd az elmúlt évek néhány kiemelkedő ágazati mutatóját elemzem. A tények ismeretében - egy SWOT analízis segítségével - rávilágítok a föbb lehetőségekre, gyengeségekre, nehézségekre és fenyegetettségekre.

\section{A BAROMFIÁGAZAT KIALAKULÁSA - A XVIII. SZÁZADTÓL NAPJAINKIG}

A magyar baromfitenyésztés komoly hagyományokkal rendelkezik, és jelene is elismert. A 19. század elsö évtizedeiben a nyugati vármegyék „tyúkászai” már számottevő mennyiségü baromfit vásároltak fel faluról falura járva, és értékesítették Ausztria piacain, elsősorban Bécsben és Grazban. A kiegyezés utáni viszonylag kedvezőbb gazdasági helyzet előnyös feltételeket teremtett a baromfikereskedelem számára is. Megjelentek a fejlettebb koncepcióval rendelkező baromfi- és gyümölcskereskedők, és állandó telephelyeket létesítettek a cikkeik szempontjából legfontosabb mezőgazdasági központokban. Benedek József volt az elsö, aki iparengedélyt kapott 1870-ben baromfi-, tojás- és gyümölcskereskedés gyakorlására. Több mint fél évszázadon keresztül hizlalta, készítette elö vagy dolgozta fel a baromfit. Telephely bővítési nehézségek miatt 1928-ban Kecskemétre tette át a székhelyét, ahol csakhamar felépült a baromfihizlalda, a vágó-, a kopasztó-, a csomagoloüzem és a hütőház (Szovátay, 2001).

Az I. Világháború okozta gazdasági károk, a trianoni békeszerződés következményei, a rendkívüli mértékü infláció a magyar baromfiipar tevékenységére is rányomta bélyegét és az újbóli részleges fellendülés csak a konszolidáció után következett be. A csak lassan helyreálló árutermelés és ipari feldolgozás igen szerény mértékü exportot tett lehetővé az első békeévekben, de a húszas évek derekán a harmadára zsugorodott ország vágottbaromfi- 
kivitele már megközelítette az I. Világháború elötti évekét, és a világgazdasági válság után gyors ütemben túlhaladta azt. Az 1960-as évek elején hazánkban is nagy átalakulás történt az ágazatban, elterjedt az egyhasznositású húscsirkék és tojótyúkok intenzív iparszerü tartása, a hús, illetve a májhizlalásra nevelt libák, kacsák tenyésztése. A baromfitermék előállítása fokozatosan növekedett, 1988-ban elérte a 680 ezer tonnát. Az ágazat exportorientált maradt. Nyugat-Európa mellett a keleti országok, föleg a volt Szovjetunió jelentette a legnagyobb felvevõ piacot. (Kirsch et al., 1986)

A rendszerváltást követỏen megtorpant a baromfitenyésztés fejlödése, a biztos keleti piacok elvesztésének következtében az export jelentösen csökkent, az 1988-as 231 ezer tonnáról 1994-re 82 ezerre esett vissza. Rövid hullámvölgy után a termelés ismét növekedett, a hazai baromfitermék fogyasztás az egészséges táplálkozás jegyében fokozódott, meghaladta az egy före esỏ évi $35 \mathrm{~kg}$-ot, a kiváló minőségü magyar áru az uniós országok piacain is jól értékesíthető volt. 2001-re az összes baromfitermék kibocsátás 690 ezer tonnával elérte a korábbi csúcsot, és az export is 130 ezer tonnával kedvező képet mutatott. A kelet-európai országok között Magyarország vezető szerepet töltött be a baromfitenyésztésben.

$\mathrm{Az}$ EU csatlakozás egy új helyzetet teremtett. Az uniós állat-egészségügyi és élelmiszerhigéniai normák betartása, az állatjóléti követelmények, a nyílt piaci verseny, beleértve a harmadik országból származó olcsó importot is, a tỏkeellátottság hiánya, valamint a támogatási rendszer szükössége, komoly nehézségeket jelent az ágazat számára. (Fürj, 2008).

Az újabb csapást az ágazatra a 2005-ben Európában megjelent, majd 2006-ban Magyarországon is felbukkant madárinfluenza vírus jelentette. A riogatás, pánikkeltés rendkívül sikeresen söpört végig Magyarországon. Kis túlzással azt is mondhatnánk, hogy nagyobb kárt okozott, mint amekkora maga a veszély, amelyre felhívta a figyelmet. (Böő, 2006)

\section{A VÁGÓCSIRKE FELVÁSÁRLÁSA}

A 2007. évi januári-februári időszak kedvezőnek bizonyult. A későbbiekben az ágazatot keltető-tojás és napos-hiány jellemezte. Ekkor a vásárlóknál húshiány jelentkezett, kismértékü áremelést eredményezve. A vágóáru felvásárlási ára (1. ábra) is ezek szerint alakult, az elsö két hónapban a kötöttség miatt kiegyenlítetten $180 \mathrm{Ft} / \mathrm{kg}$ körül állapodott meg, majd enyhe többletet és a későbbi hiányt követve, gyorsan csökkent, majd hasonló mértékben néhány forintot nőtt. A nyáron kialakult egy piaci egyensúly, a keltetési eredmények, a vágott áru mennyisége megközelítette a tavalyi értékeket, és szélsőségektöl mentes volt. Mảjus 1. után megszünt a termelök részére biztositott két támogatási forma: az élősúly kilogrammonként 9,50 Ft-os állatjóléti támogatás, és a $2 \mathrm{Ft} /$ kilogrammos gyógyszertámogatás. Emiatt és a takarmányárak emelkedésének hatására június elejétöl a felvásárlási árak is növekedésnek indultak. A felvásárlási átlagár emelkedése a 45 . héten $223,79 \mathrm{Ft} / \mathrm{kg}$-nál gyakorlatilag megállt. Az 50 . héten $225,27 \mathrm{Ft} / \mathrm{kg}$ csúcsot ért el, de az 52 . heti felvásárlási átlagár $26 \%$-kal volt magasabb, mint 2007 . első hetében. 


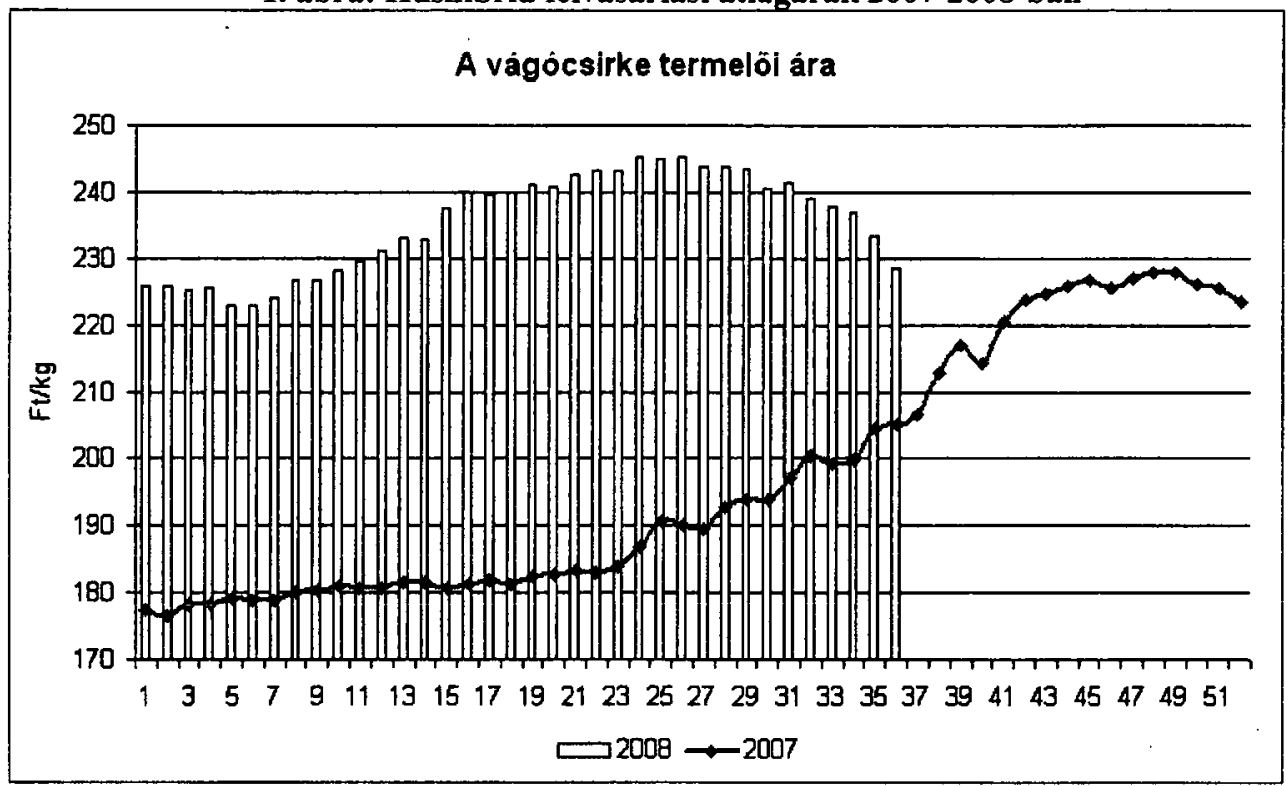

Forrás: www.akii.hu

Az aszály miatti alacsony gabonatermelés, illetve a kukorica egyre nagyobb arányú bioetanol célú felhasználása következtében jelentősen emelkedtek a takarmánykeverékek árai (2. ábra). Az emelkedés mértéke nagyobb volt, mint a felvásárlási áraké, így a termelök önköltsége is nagyobb arányban növekedett. A megoldást a saját takarmány elöállítása jelentheti. (Szabó, 2007., Bárány, 2008.)

2. ábra: Húshibrid takarmányárak 2007-ben

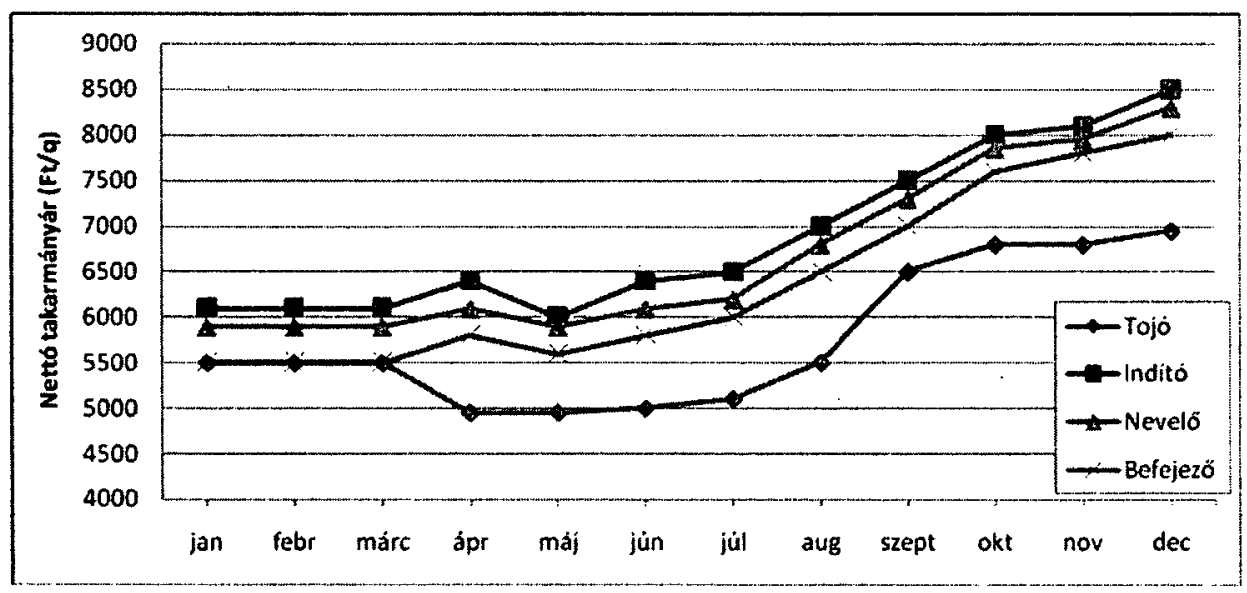

Forrás: Baromfiágazat, 2008

2008-ban a vágócsirke felvásárlási ára 220 és $245 \mathrm{Ft} / \mathrm{kg}$ között mozog, a 24. héten 243,5 Ft/kg-os csúcsot ért el. Azóta enyhe csökkenést mutat. Ez két fő okra vezethető vissza, 
egyrészt az országba érkezett import csirke, másrészt a betakarítás utánra remélt gabonaár csökkenés hatása, - annak ellenére, hogy a takarmányárak valójában még nem csökkentek. Ez a termelőknél további jövedelmezőség-romláshoz vezethet (Kuli, 2008.)

\section{A VÁGÓCSIRKE TERMELÉSE, ÉRTÉKESÍTÉSE}

\section{1. táblázat: Vágócsirke feldolgozás (2000-2007, tonna) ${ }^{(1)}$}

\begin{tabular}{|c|c|c|}
\hline Év & $\begin{array}{c}\text { Feldolgozott } \\
\text { mennyiség }(\mathrm{t})\end{array}$ & $\begin{array}{c}\text { Változás } \\
2000=100 \%\end{array}$ \\
\hline 2000 & 155619 & - \\
\hline 2001 & 170829 & 109,77 \\
\hline 2002 & 170188 & 109,36 \\
\hline 2003 & 173434 & 111,44 \\
\hline 2004 & 178535 & 114,72 \\
\hline 2005 & 181836 & 116,85 \\
\hline 2006 & 165269 & 106,20 \\
\hline 2007 & 162624 & 104,50 \\
\hline
\end{tabular}

\section{Forrás: Baromfi Termék Tanács}

${ }^{(1)} \mathrm{Az}$ adatok csak azokat a vágásokat tartalmazzák, amelyek a BTT tagjainak üzemeiben történtek.

A broiler-termeléssel kapcsolatosan a Baromfi Termék Tanács (BTT) szolgált adatokkal. A tagjai által elsődlegesen feldolgozott vágócsirke mennyiségét foglaltam össze az 1. táblázatban. Az elmúlt nyolc évet vizsgálva azt tapasztaljuk, hogy 2005-ig folyamatosan nő a feldolgozott mennyiség, míg 2006-tól kezdődően csökkenést mutat. Ugyanakkor meg kell jegyezni, hogy a 2000. évhez képest még mindig több vágócsirke került elsődleges feldolgozásra.

A feldolgozáshoz hasonlóan a belföldi értékesítés mennyisége is fokozatosan csökkent az elmúlt 2 évben (2. táblázat). A fordulópontot jelentő 2005. óta $10 \%$-kal lett kisebb az eladott vágócsirke tétele. Az exportált vágócsirke mennyisége már 2001. óta csökkenő tendenciát mutat, a tavalyi évben már csak a korábbi mennyiség $40 \%$-át tudták értékesíteni.

\section{2. táblázat: A vágóbaromfi-értékesítés alakulása 2000-2007 között (tonna)}

\begin{tabular}{|c|c|c|c|c|}
\hline & \multicolumn{2}{|c|}{ Értékesített mennyiség $(\mathrm{t})$} & \multicolumn{2}{c|}{$\begin{array}{c}\text { Változás } \\
(2000=100 \%)\end{array}$} \\
\hline év & belföld & export & belföld & export \\
\hline 2000 & 106249 & 33574 & - & - \\
\hline 2001 & 108607 & 36935 & 102,22 & 110,01 \\
\hline 2002 & 120166 & 35479 & 113,10 & 105,67 \\
\hline 2003 & 130128 & 27381 & 122,47 & 81,55 \\
\hline 2004 & 146063 & 26754 & 137,47 & 79,69 \\
\hline 2005 & 155326 & 22718 & 146,19 & 67,66 \\
\hline 2006 & 149726 & 17341 & 140,92 & 51,65 \\
\hline 2007 & 139985 & 14922 & 131,75 & 44,45 \\
\hline
\end{tabular}

Forrás: Magyar Baromfi, 2000-2008. 
A belföldi forgalom gyengülésének több oka is van (Földi, 2008):

- Az EU-csatlakozással nött az import mennyisége,

- Nőtt az élelmiszerek ára,

- Csökkent a vásárlóerő,

- A feketegazdaság egyre nagyobb tért nyert,

○ Csökkent a sertéshús ára.

Bár a magyar baromfitermelök egyre inkább versenyképesek (például a broilerhízlalóknak már több mint a fele felújitott, korszerü körülmények között müködik), mégis, a Magyarországra importált baromfi mennyisége növekszik. Ez ellen nem tehetünk semmilyen szankciót, csak akkor, ha az importált baromfira egészségügyi kifogásunk van. Néhány országban jobbak a baromfitermelés közgazdasági feltételei, így ők a magyar vágóhidakra olcsóbban tudnak termelni. Ugyanakkor tény, hogy a magyar csirke genetikai alapja sokkal jobb, mint pl. a braziloké, vagy a franciáké (Kállay, 2007.).

\section{KÖVETKEZTETÉSEK, JAVASLATOK}

$\mathrm{Az}$ eddig leírtak összegzéseként elkészítettem a broiler-ágazat SWOT-analizisét. A 3. táblázatban látható tényezökön kívuil még sok mást is fel lehetne sorolni, de a tanulmányban ezeket tartottam fontosnak.

\section{3. táblázat: A broiler ágazat SWOT-analizise}

\begin{tabular}{|l|l|}
\hline $\begin{array}{l}\text { Erösségek: } \\
\text { a baromfitenyésztés komoly hagyománya, } \\
\text { a jó genetikájú állomány, } \\
\text { a kitünö szakmai háttér. }\end{array}$ & $\begin{array}{l}\text { Gyengeségek: } \\
\text { a tökehiány, } \\
\text { az import alacsony ára, } \\
\text { a vásárlóerő csökkenése, } \\
\text { a támogatási rendszer szükössége }\end{array}$ \\
$\begin{array}{l}\text { A pályázati források } \\
\text { az alternatív és megújuló energiák } \\
\text { alkalmazása, } \\
\text { termelöi szövetkezetek létrehozása, } \\
\text { alkupozíció növelése }\end{array}$ & $\begin{array}{l}\text { Fenyegetettségek: } \\
\text { a madárinfluenza, } \\
\text { Kína, India, Oroszország, Brazília, export- } \\
\text { nagyhatalommá válása, } \\
\text { a mezögazdasági termöterületek csökkenése } \\
\text { (pl. városok építkezései miatt), } \\
\text { a takarmányárak növekedése. }\end{array}$ \\
\hline
\end{tabular}

Összességében elmondható, hogy az elmúlt évek inkább kihívások voltak a broilerágazat számára mint sikerek, de remélhetöleg ezt a mélyrepülést kisebb fellendülés fogja követni. 


\section{IRODALOMJEGYZÉK}

Bárány L. (2008): Álláspont: (Tan)-évnyitó helyett Magyar baromfi 49. évf. 2. szám 4-5. oldal

Böö I. (2006): Az intenziv pecsenyecsirke termelés és az állatvédelem összefüggéseinek néhány kérdése I. Agrárágazat. VI. évf. 6. szám http://www.pointernet.pds.hu/ujsagok/agraragazat/2006/06/20060615161004959000000 471.html (letöltve: 2008. 09. 18.)

Földi P. (2008): Álláspont: Dávid parittya nélkül. Magyar Baromfi. 2008. 49. évf. 1. szám 46. oldal

Fürj Z. (2008.): A magyarországi baromfiágazat helyzetelemzése. Szakdolgozat, SZTE-MK Szeged

Kállay, B. (2007): Képesség, készség -szükség Magyar Baromfi, 48. évf. 5. szám, 4-6. oldal

Kirsch J. - Szabó L. - Tóth-Zsiga I. (1986): A magyar élelmiszeripar története, Mezőgazdasági Kiadó

Kuli B. (2008): Magyar Broilerszövetség Magyar Baromfi, 49. évf. 8. szám 10. oldal

Szabó I. (2007): A broiler ágazat helyzete - riport. Baromfiágazat

Szovátay A. (2001): A baromfitenyésztés rövid története a régmúlt időktöl napjainkig I. 4. évfolyam 4. szám 22-26. 0 .

http://www.akii.hu/gazdel/_frames.htm (letöltve:2008. 09. 20.) 